\title{
1: 198708730-198716790
}

National Cancer Institute

\section{Source}

National Cancer Institute. 1:198708730-198716790. NCI Thesaurus. Code C42178.

Physical location of ELF3_Gene 